TURIZAM

Volume 25 , Issue 3

$110-120(2021)$

ORIGINAL

SCIENTIFIC PAPER

\title{
Determining Success Factors for Business Tourism Destinations: Evidence from Zlatibor (Serbia)
}

\author{
Vanja PavlukovićA, Stojan VukovićA ${ }^{A}$ Marija CimbaljevićA \\ Received: August 2020 | Accepted: January 2021 \\ DOI: 10.5937/turizam25-28201
}

\begin{abstract}
Business tourism is an important and fast-growing sector in the global tourism industry. It is often positioned as a crucial part of an economic development strategy, particularly in emerging destinations, such as Serbia. As there is a growing number of destinations that recognized benefits of business tourism development, tourism professionals and destination management must be aware of key success factors for business tourism destinations, namely factors that influence the choice of host destination for a business event. Serbia has been one of the growing meeting destinations in Europe in the last decade, and Zlatibor is a desirable tourist destination in the country, with a good reputation in hosting meetings primarily in the field of medicine. This study aims to examine the success factors for business tourism destination and the attractiveness of Zlatibor for holding business events from destination stakeholders' perspective. The results could be of interest to all stakeholders in business tourism.
\end{abstract}

Keywords: business tourism, meetings industry, destination selection criteria, convention bureau, Zlatibor

\section{Introduction}

Business tourism is deemed an important and fast-growing sector in the global tourism market (United Nations World Tourism Organization [UNWTO] \& European Travel Commission [ETC], 2015; World Travel \& Tourism Council, 2017; Pavluković, Cimbaljević, 2020). It has been considered as one of the most desirable forms of tourism development at destinations worldwide, as the spending of organizers and participants on business events related services (e.g., meeting facilities, accommodation, catering, transportation) and on tourism activities (e.g., dining, shopping, leisure, tours) contributes to the economic growth of host destinations (Han, Hwang, 2017; Han et al., 2019). Therefore, business tourism often plays a leading role in the growth of the wider travel and tourism sector, and it is positioned as a crucial part of an

A University of Novi Sad, Faculty of Sciences, Department of Geography, Tourism and Hotel Management, Trg Dositeja Obradovića 3, 21000 Novi Sad, Serbia

Corresponding author: vanja.dragicevic@dgt.uns.ac.rs 
economic development strategy, particularly in emerging destinations, such as Serbia (Pavluković, Cimbaljević, 2020). Most of these destinations have established a convention bureau at a country or city level, with the main task to promote a destination and to attract business events (UNWTO \& ETC, 2015; McCartney, 2008). As there is a growing number of destinations that recognized the benefits of business tourism development, the competition is more intensive now than it used to be (Dragićević et al., 2012). Therefore, tourism professionals and destination management must be aware of key success factors for business tourism destinations, namely factors that influence meeting planners' choice of a destination to hold meetings, conventions, congresses, incentives, and other business events.

Serbia has been one of the growing meeting destinations in Europe in the last decade. According to the latest ICCA Statistics report 2019, Serbia is positioned as 5oth on world rankings of countries by the number of international association meetings, and 26th among European destinations. It is estimated that at least one third of total international arrivals in Serbia are business tourists, most of them being centered in the capital - Belgrade (UNWTO \& ETC, 2015). Serbia Convention Bureau (SCB) was established in 2007, as a department within the National Tourism Organization of Serbia (NTOS), with the primary role to promote Serbia as an attractive meeting destination. SCB highlights five key destinations in Serbia for business events: three cities, Belgrade as the capital, Novi Sad and Subotica, and two mountains Kopaonik and Zlatibor.

Zlatibor is a top-rated tourist destination in Serbia, and it is well-known as a destination for meetings in the field of medicine and pharmacy (Bučić et al., 2015). Therefore, we chose it as a study area to examine the success factors for business tourism destination and to investigate the attractiveness of Zlatibor for holding business events from destination stakeholders' perspective. Moreover, we investigated if there were any statistically significant differences in the success factors for business tourism destination between the respondents of different gender, and the sector they worked in (public or private).

\section{Literature review}

The business tourism (sometimes referred to as the meetings, incentives, conferences, and exhibitions - or MICE sector) includes activities based on the organization, promotion, sales and delivery of meetings and events; products and services that include corporate, association and government meetings, corporate incentives, seminars, congresses, conferences, conventions, exhibitions, and fairs (UNWTO \& ETC, 2015). More and more destinations are investing resources in this growing segment of tourism, specifically in the infrastructure, because they recognize its potential to create positive economic and social impact.

Numerous studies have investigated specific destination factors that influence the decision-making process of meeting planners and a selection of a destination for holding a specific business event (Baloglu, Love, 2001; Chacko, Fenich, 2000; Chen, 2006; Crouch, Ritchie, 1997; Crouch, Louviere, 2004; DiPietro et al., 2008; Dragićević et al., 2012; Kim, Kim, 2004; Qu et al., 2000; Zhang et al., 2007). A business tourism destination has to offer a suitable venue for the meeting, sufficient accommodation facilities, tourist attractions, good accessibility to the generating markets, and an efficient transport system within the destination (Swarbrooke, Horner, 2001). According to Crouch and Weber (2002), the service provided in a destination and its facilities are critical to the success of a meeting destination. Attractive tourist destinations are 
also desirable places for hosting various business events. The more attractive the destination is, the more attractive the event would be for potential attendees (Dunjić et al., 2012).

Crouch and Ritchie (1997) identified eight primary categories of destination attributes, that influence a choice and a success of a meeting destination: accessibility (cost, time, frequency, visa), local support (local chapter, convention and visitors' bureau/convention center, subsidies), extra conference opportunity (such as entertainment, shopping, sightseeing, recreation, and professional opportunities), accommodation facilities (capacity, cost, service quality, security, and availability), meeting facilities (capacity, cost, ambiance, security, availability, previous experience), information (destination reputation and marketing), site environment (including climate, setting, and infrastructure) and other criteria. In a study of the Qu et al. (200o) on Hong Kong as an international conference destination in South-east Asia, accommodation, convention facilities, accessibility, safety, and infrastructure were found as important destination selection factors. Kim and Kim (2004) highlighted that meeting room facilities, service quality, restaurants, transportation, and destination attractiveness were significant attributes for choosing Seoul as a destination for international conferences. Although the literature has emphasized the importance of the available meeting and accommodation facilities, it is evident that some additional destination factors (such as accessibility, attractive pre and postevent recreational or vacationing opportunities, appealing destination image) play critical roles in the destination selection process (Crouch, Louviere, 2004). "Destinations need to create unique combinations of attributes to develop strong competitive positions" (Crouch, Louviere, 2004, p.128), using knowledge of the factors that meeting planners and buyers value most in their destination choice decisions.

The study of UNWTO and ETC (2015) found that international associations conventions and congresses favor destinations, which offer the following: active membership of the association at the proposed destination; meeting facilities and technical support; local support and subvention; accessibility; safety and security; shopping and entertainment, pre and post tours for delegates; support services at a destination; hotel facilities; destination appeal; local experience and expertise, etc. Similar success destination attributes were identified for corporate meetings: a popular destination for hosting successful events, with desirable destination image, low-risk destinations with infrastructure (meeting facilities), excellent services and easier accessibility.

In Serbia, there is little research about business tourism in general and specifically the attractiveness of destinations and success factors that influence the decision-making process of meeting planners. Several previous studies addressed the conference attendees' satisfaction in Serbia (Dragićević et al., 2010; Dragićević et al., 2011; Dunjić et al., 2012), business tourism destination competitiveness (Dragićević et al., 2012), factors affecting conference participation decision-making from the academics' perspective (Pavluković, Cimbaljević, 2020). Moreover, there is a lack of research on Zlatibor as a business tourism destination. However, it is recognized in strategic tourism documents as one of the key tourism destinations in Serbia for the development of this form of tourism (Business (master) plan of tourism destination Zlatibor-Zlatar, 2007; Tourism development strategy of the Republic of Serbia 2016-2025). Therefore, we believe this study is of importance, both for theory on business tourism as well as practice. 


\section{Methodology}

To achieve the aim of the study, the research instrument was developed based on a literature review on business tourism destinations and the factors that influence destination selection for holding business events (Crouch, Ritchie, 1997; Qu et al., 2000; Dragićević et al., 2012). The final questionnaire was composed of three sections. In the first section, the socio-demographic characteristics of the respondents were examined. The second part consisted of a series of questions regarding the need to establish a convention bureau on Zlatibor, as local support in the form of convention bureau was identified in the literature as an essential success factor for business tourism destination (Crouch, Ritchie, 1997; UNWTO \& ETC, 2015). In the last segment of the questionnaire, the respondents were asked to express their agreement with the statements on the attractiveness of Zlatibor as a business tourism destination and its attributes on a five-point Likert scale ranging from 1 (I do not agree at all) to 5 (I completely agree). The questionnaire was created using Google Docs and distributed electronically to destination tourism-related stakeholders - representatives of the Zlatibor tourism industry, using their official email addresses. The survey was conducted on Zlatibor during May and June 2019, and 123 respondents agreed to participate in the study. The data was processed with the statistical package SPSS 20. The following analyses were carried out: descriptive statistics and the independent sample t-test.

\section{Study area}

Good geographical position, natural and cultural heritage and hospitality of the locals at Zlatibor have influenced the development of tourism in this region. Zlatibor is located in the southern part of Serbia, about $230 \mathrm{~km}$ from the international airport in Belgrade. It has attractive natural and cultural heritage (Gostilje waterfall, lake Ribničko, Obudojevica lake, Stopića cave, and Potpećka cave: Sirogojno - open-air museum "Staro selo", Uvac Monastery, Dubrava Monastery, Mokra Gora and "Šarganska osmica", wooden churches in Jablanica and Dobroselica), providing opportunities for diverse pre and post-event tours for attendees.

Recently, great attention has been paid to the development of business tourism on Zlatibor with investments in meeting facilities and infrastructure. The meeting venues on Zlatibor range from high-quality hotels to unusual venues. Natural resources, cultural and historical heritage, and good quality of accommodation services, as well as adequate venues, have increased the number of business events and tourists from year to year. According to the Statistical Office of the Republic of Serbia (2020), about 240,0oo tourists visited Zlatibor in 2019, mostly domestic tourists (about 30\% were foreign tourists). The largest number of foreign tourists were from Montenegro, Bosnia and Herzegovina and China.

\section{Respondents' Profile}

The research sample consists of 83 female respondents (67.5\%) and 40 male respondents (32.5\%), with the largest number of respondents belonging to the age group between 25 and 35 years (49.6\%), followed by the group of 36-50 years (30.9\%). Almost one third of the respondents have completed college (30.1\%). In the second place are respondents with completed high school $(29.3 \%)$, while the respondents with bachelor's degrees represent $27.6 \%$ of the sample. The least number of respondents have a master's or doctoral degree, only $13 \%$. The majority of the respondents are employed in hotels $(61.8 \%)$, tourist organizations, and travel agencies. Moreo- 
ver, the employees of hostels, development agencies, as well as two teachers from the tourism high school participated in the research.

\section{Results}

The analysis of the research results shows that of the total number of the respondents, $44 \%$ of them are engaged in organizing business events. They pointed out that most of business events on Zlatibor are currently organized in the field of medicine and pharmacy $(51.2 \%)$, followed by economics (23.6\%). In third place are business events in the field of tourism and hospitality (13\%), while events in the field of IT sector, finance, and insurance are somewhat less represented.

The respondents generally believe that there is a need to establish a convention bureau at Zlatibor (60\%). One third of them (30\%) did not have a definite opinion, more precisely, they were not sure, which indicates that respondents should be informed and educated about the role and activities of the convention bureau in the development of business tourism in the destination. In contrast, only $10 \%$ of the respondents don't think it's necessary to establish a bureau to improve Zlatibor as a business tourism destination.

The respondents who support the establishment of a convention bureau at Zlatibor, expect from this institution: to improve Zlatibor as a business tourism destination, to increase tourist traffic, reduce seasonality and increase the length of stay of tourists, further to provide training for the staff working in the tourism and meetings industry and improve the quality of venues and cooperation among the stakeholders in Zlatibor tourism industry. Also, in their opinion, the convention bureau should perform the roles of gathering all stakeholders in the tourism industry of Zlatibor, promotion of Zlatibor as a business tourism destination, and supporting the organization of the event. Most respondents (67.5\%) think that the convention bureau of Zlatibor would be helpful, while on the other hand, only $8.9 \%$ of them currently cooperate with the Convention Bureau of Serbia.

In the opinion of the respondents, the main competitors of Zlatibor as a business tourism destination are the following destinations in Serbia: Belgrade, Kopaonik, Tara, Vrnjačka, and Soko Banja. Also, more than $70 \%$ of the respondents believe that the establishment of the Zlatibor convention bureau would improve the infrastructure for organizing business events, reduce the seasonality of the destination and increase the number of organized business events on Zlatibor. These data indicate the positive attitude of the respondents towards business tourism development at Zlatibor and the establishment of a convention bureau at this destination. Moreover, the respondents stated that Zlatibor convention bureau should promote Zlatibor as a business tourism destination primarily in the European market (48\%), in the region (30.9\%), in the country (14.6\%), while only $6.5 \%$ stated that the promotion should take place outside Europe. More than one third of the respondents (39\%) added that various national professional associations should be the key target segment for organizing conferences and other similar events at Zlatibor, followed by the companies from the region (23.6\%), regional professional associations, as well as companies from Serbia. Also, the respondents stated that the companies that organize internal events (e.g., team building programs, incentive programs) for their employees were and should be important segment for both the Zlatibor tourism industry and the meetings industry.

To investigate how the respondents perceive Zlatibor as a business tourism destination, they were asked to evaluate 13 statements - factors that are important for successful business tourism development at a destination. 
Essential factors for organizing any business event are destination image, venues, quality of accommodation facilities, infrastructure, traffic connections, safety at a destination, hospitable residents, adequate local support, and others. All these factors in the case of Zlatibor are evaluated with high grades above 4, on the Likert scale from 1 - the lowest rate to 5 - the highest rate, except factors traffic connections, local support, and the quality of human resources (mean value below 4). Also, more than $90 \%$ of the respondents perceive Zlatibor as an attractive destination for organizing business events $(M=4.60)$. The respondents best rated the statement that Zlatibor offered opportunities for creating various tours and excursions before and/ or after a business event $(M=4.62)$. Zlatibor is perceived as a safe destination $(M=4.56)$, which is very important for all visitors nowadays, and this factor plays a vital role in general tourism development. The factor by which Serbia, and even Zlatibor, stands out among the destinations, certainly is the hospitality of the hosts $(M=4.38)$, by which the Zlatibor region is very well known. A large number of respondents (55\%) fully agree that Zlatibor has a good reputation among the organizers of business events. Respondents generally or entirely agree that there is adequate staff to organize this type of event and that there is local support in organizing the event. About 50\% of respondents agree that the service of organizing business events on Zlatibor is in line with quality, which is very important, especially today when the competition is increasing.

Table 1. Zlatibor as a destination of business tourism - the perception of the respondents

\begin{tabular}{|l|c|c|}
\hline Statements & M* & SD* \\
\hline Zlatibor is an attractive destination for organizing business events & 4.60 & 0.64 \\
\hline Zlatibor has a quality offer of various venues for organizing business events & 4.22 & 0.82 \\
\hline Zlatibor has a quality offer of various accommodation facilities for business participants & 4.50 & 0.78 \\
\hline Zlatibor has good traffic connections with destinations in the country and the region & 3.80 & 1.14 \\
\hline Zlatibor has a quality gastronomic offer & 4.50 & 0.77 \\
\hline $\begin{array}{l}\text { Zlatibor offers opportunities to create various tours and excursions before and/or after a } \\
\text { business event }\end{array}$ & 4.62 & 0.69 \\
\hline Zlatibor offers various entertainment opportunities & 4.42 & 0.76 \\
\hline Zlatibor is a safe destination for organizers and participants of business events & 4.56 & 0.83 \\
\hline The local population of Zlatibor is hospitable & 4.38 & 0.85 \\
\hline Zlatibor has a good reputation among business event organizers & 4.32 & 0.86 \\
\hline There is local support for the development of business tourism on Zlatibor & 3.99 & 1.00 \\
\hline On Zlatibor, there are quality human resources that work on the organization of business events. & 3.86 & 0.99 \\
\hline Good value for money & 4.07 & 0.78 \\
\hline
\end{tabular}

*M- mean value, SD-standard deviation

To examine if there are any gender differences in the perception of Zlatibor attractiveness as a business tourism destination, the independent sample t-test was conducted (Table 2).

Statistically significant differences were found between male and female respondents at the level of significance of $\mathrm{p}<0.01$ in their perception of Zlatibor traffic connections with destinations in the country and the region, opportunities to create various tours and excursions before and/or after a business event. Namely, males assigned higher mean values for the statement Zlatibor has good traffic connections with destinations in the country and the region. At the same time, female respondents give higher grade for the opportunities for creating different tours and excursions before and after a business event. It is important to note that in other 
answers of the respondents on their perception about Zlatibor as a business tourism destination, no statistically significant differences were found between men and women.

Table 2. Gender differences in the perception of Zlatibor as a business tourism destination

\begin{tabular}{|c|c|c|c|}
\hline Statements & Gender & $M(S D) *$ & $\mathrm{p}^{*}$ \\
\hline \multirow{2}{*}{ Zlatibor is an attractive destination for organizing business events } & Male & $4.47(0.71)$ & \multirow{2}{*}{0.13} \\
\hline & Female & $4.66(0.61)$ & \\
\hline \multirow{2}{*}{ Zlatibor has a quality offer of various spaces for organizing business events } & Male & $4.32(0.61)$ & \multirow{2}{*}{0.36} \\
\hline & Female & $4.18(0.91)$ & \\
\hline \multirow{2}{*}{ Zlatibor has a quality offer of various accommodation facilities for business participants } & Male & $4.40(0.77)$ & \multirow{2}{*}{0.30} \\
\hline & Female & $4.55(0.78)$ & \\
\hline \multirow{2}{*}{ Zlatibor has good traffic connections with destinations in the country and the region } & Male & $4.15(1.02)$ & \multirow{2}{*}{0.02} \\
\hline & Female & $3.63(1.17)$ & \\
\hline \multirow{2}{*}{ Zlatibor has a quality gastronomic offer } & Male & $4.47(0.71)$ & \multirow{2}{*}{0.77} \\
\hline & Female & $4.51(0.80)$ & \\
\hline \multirow{2}{*}{$\begin{array}{l}\text { Zlatibor offers opportunities to create various tours and excursions before and/or after a } \\
\text { business event }\end{array}$} & Male & $4.37(0.89)$ & \multirow{2}{*}{0.00} \\
\hline & Female & $4.74(0.53)$ & \\
\hline \multirow{2}{*}{ Zlatibor offers various entertainment opportunities } & Male & $4.45(0.78)$ & \multirow{2}{*}{0.78} \\
\hline & Female & $4.41(0.76)$ & \\
\hline \multirow{2}{*}{ Zlatibor is a safe destination for organizers and participants of business events } & Male & $4.50(0.81)$ & \multirow{2}{*}{0.52} \\
\hline & Female & $4.60(0.84)$ & \\
\hline \multirow{2}{*}{ The local population of Zlatibor is hospitable } & Male & $4.27(0.78)$ & \multirow{2}{*}{0.33} \\
\hline & Female & $4.43(0.88)$ & \\
\hline \multirow{2}{*}{ Zlatibor has a good reputation among business event organizers } & Male & $4.17(0.81)$ & \multirow{2}{*}{0.18} \\
\hline & Female & $4.39(0.88)$ & \\
\hline \multirow{2}{*}{ There is local support for the development of business tourism on Zlatibor } & Male & $4.15(1.05)$ & \multirow{2}{*}{0.22} \\
\hline & Female & $3.91(0.97)$ & \\
\hline \multirow{2}{*}{$\begin{array}{l}\text { On Zlatibor, there are quality human resources that work on the organization of business } \\
\text { events. }\end{array}$} & Male & $4.05(0.93)$ & \multirow{2}{*}{0.14} \\
\hline & Female & $3.77(1.01)$ & \\
\hline \multirow{2}{*}{ Zlatibor offers good value for money. } & Male & $4.07(0.85)$ & \multirow{2}{*}{0.98} \\
\hline & Female & $4.07(0.74)$ & \\
\hline
\end{tabular}

${ }^{*} M$ - mean value, SD- standard deviation, $p$ - value - level of statistical significance at 0.01

To examine if there are any differences in the perception of Zlatibor as a business tourism destination between two groups of the respondents, those working in public and the private sector, the independent sample t-test was performed. The results in Table 3 indicate that there are no statistically significant differences in the perception of Zlatibor as a business tourism destination among the respondents working in public and those working in the private sector. 
Table 3. Differences in the perception of Zlatibor as a business tourism destination between the respondents working in the public sector and the private sector

\begin{tabular}{|c|c|c|c|}
\hline Statements & Sector & $M(S D)^{*}$ & $\mathrm{P}^{*}$ \\
\hline \multirow{2}{*}{ Zlatibor is an attractive destination for organizing business events } & Public & $4.67(0.59)$ & \multirow{2}{*}{0.45} \\
\hline & Private & $4.57(0.66)$ & \\
\hline \multirow{2}{*}{ Zlatibor has a quality offer of various spaces for organizing business events } & Public & $4.32(0.65)$ & \multirow{2}{*}{0.46} \\
\hline & Private & $4.19(0.88)$ & \\
\hline \multirow{2}{*}{ Zlatibor has a quality offer of various accommodation facilities for business participants } & Public & $4.61(0.55)$ & \multirow{2}{*}{0.37} \\
\hline & Private & $4.46(0.84)$ & \\
\hline \multirow{2}{*}{ Zlatibor has good traffic connections with destinations in the country and the region } & Public & $3.90(0.87)$ & \multirow{2}{*}{0.58} \\
\hline & Private & $3.77(1.23)$ & \\
\hline \multirow{2}{*}{ Zlatibor has a quality gastronomic offer } & Public & $4.58(0.80)$ & \multirow{2}{*}{0.52} \\
\hline & Private & $4.47(0.76)$ & \\
\hline \multirow{2}{*}{$\begin{array}{l}\text { Zlatibor offers opportunities to create various tours and excursions before and/or after a } \\
\text { business event }\end{array}$} & Public & $4.77(0.61)$ & \multirow{2}{*}{0.17} \\
\hline & Private & $4.57(0.71)$ & \\
\hline \multirow{2}{*}{ Zlatibor offers various entertainment opportunities } & Public & $4.38(0.76)$ & \multirow{2}{*}{0.76} \\
\hline & Private & $4.43(0.77)$ & \\
\hline \multirow{2}{*}{ Zlatibor is a safe destination for organizers and participants of business events } & Public & $4.74(0.68)$ & \multirow{2}{*}{0.18} \\
\hline & Private & $4.51(0.87)$ & \\
\hline \multirow{2}{*}{ The local population of Zlatibor is hospitable } & Public & $4.48(0.88)$ & \multirow{2}{*}{0.44} \\
\hline & Private & $4.34(0.84)$ & \\
\hline \multirow{2}{*}{ Zlatibor has a good reputation among business event organizers } & Public & $4.32(0.87)$ & \multirow{2}{*}{0.98} \\
\hline & Private & $4.32(0.86)$ & \\
\hline \multirow{2}{*}{ There is local support for the development of business tourism on Zlatibor } & Public & $4.12(0.80)$ & \multirow{2}{*}{0.38} \\
\hline & Private & $3.94(1.06)$ & \\
\hline \multirow{2}{*}{$\begin{array}{l}\text { On Zlatibor, there are quality human resources that work on the organization of business } \\
\text { events. }\end{array}$} & Public & $3.87(0.76)$ & \multirow{2}{*}{0.95} \\
\hline & Private & $3.85(1.06)$ & \\
\hline \multirow{2}{*}{ Zlatibor offers good value for money. } & Public & $4.19(0.79)$ & \multirow{2}{*}{0.32} \\
\hline & Private & $4.03(0.77)$ & \\
\hline
\end{tabular}

*M - mean value, SD-standard deviation, $p$ - value - level of statistical significance at 0.01

\section{Discussion and Conclusion}

The primary purpose of this study was to examine the factors that influence the destination selection process for holding business events and the attractiveness of Zlatibor as a business tourism destination and its attributes from the internal stakeholders' perspective.

The results of the study show that all factors, that are generally important for business tourism development in a destination, are evaluated with high grades in the case of Zlatibor. These findings are in line with the previous related works by other researchers in this field (Crouch, Ritchie, 1997; DiPietro et al., 2008; Crouch, Louviere, 2004; Kim, Kim, 2004; Qu et al., 2000; Dragićević et al., 2012; Dunjić et al., 2012; UNWTO \& ETC, 2015), which emphasize the importance of destination attractiveness, safety, accessibility, local's hospitality, local support and infrastructure in the business tourism development. 
In this study, Zlatibor is recognized as an attractive destination with a good reputation for holding business events, as well as with the quality accommodation and meeting facilities. Similar conclusions were drawn in the study of Bučić et al. (2015). Moreover, it is perceived as a destination that offers good value for money. Cost-effectiveness is identified as an important factor that influences meeting planners' destination choice both for the association and corporate events (UNWTO \& ETC, 2015). The perceived value for money, overall cost, desirable destination image, and reputation for hosting successful events were identified as important business tourism destination selection criteria in the study of DiPietro et al. (2008). The safety and security are megatrends that shape the global meetings industry (German Convention Bureau, 2013), and Zlatibor is perceived as a safe mountain destination, which could be its advantage over competitors in the region.

Accessibility of Zlatibor was rated with a lower grade compared to other statements on the business tourism destination. We believe it is because the nearest international airport is in Belgrade (more than two hours of driving). This could be a disadvantage of Zlatibor in attracting international meetings, while for regional and national meetings, it is an acceptable distance. Although several studies highlight that second-tier destinations (such as Zlatibor) successfully compete with major business tourism cities (Houdement et al., 2017), we suggest further promoting of Zlatibor primarily as a destination convenient for regional and national meetings. Moreover, the quality of human resources in the Zlatibor meetings industry is questionable for less than a third of the respondents in our study, indicating that additional training and education is needed and desirable, primarily if destination management aims to attract international meetings.

As was expected, the stakeholders involved in the tourism and meetings industry in Zlatibor, who participated voluntarily in this study, mostly support the establishment of the Zlatibor convention bureau. The literature highlights that the existence of local support in the form of convention bureau is a major consideration when choosing a host destination, particularly for association conferences and congresses (UNWTO \& ETC, 2015).

Furthermore, the findings of this study reveal that there are significant differences in some destination attributes between the respondents of a different gender. At the same time, the sector they work in does not influence their perception of Zlatibor attributes relevant to business tourism development. This finding indicates the positive attitude of the respondents both from the public and the private sector towards business tourism development at Zlatibor.

This research has provided significant contributions to the body of knowledge on the business tourism destination and its attributes or factors, which affect a destination selection process for a business event. The results could be of interest to all intermediaries and suppliers in the meeting industry, including Serbia convention bureau, destination marketing organizations, destination management companies, professional conference organizers, meeting planners, and venues.

Since the competition among destinations to host events increases, it is important to conduct further empirical research on destination selection criteria, which could help all destination stakeholders in the meetings industry in maximizing their potential to host events and gain benefits from it. Therefore, we suggest conducting similar research in other business tourism destinations in Serbia as well as in the region, to compare the results and make them more generalizable. In this study, destination stakeholders were involved, while in some future studies, it would be interesting to examine the opinion of meeting planners as well as attendees of the business events on the factors affecting the destination selection process. As the whole world is currently facing with the COVID-19 pandemic, which negatively impacts the global 
tourism and meetings industry, some future research should investigate the advantages and limitations of virtual and face-to-face meetings, and the impact of increased use of technology and virtual events on business tourism destinations.

\section{References}

Baloglu, S., Love, C. 2001. Association meeting planners' perceptions of five major convention cities: results of the pre-test. Journal of Convention E Exhibition Management 3(1), 21-30.

Business (master) plan of tourism destination Zlatibor-Zlatar 2007. Singidunum University, Belgrade.

Bučić A., Cimbaljević M., Janković M. 2015. Mogućnosti za razvoj kongresnog turizma na Zlatiboru. Zbornik radova Departmana za geografiju, turizam i hotelijerstvo 44(1), 86-95 (in Serbian).

Chacko, H. E., Fenich, G. G. 20oo. Determining the importance of US convention destination attributes. Journal of vacation marketing 6(3), 211-220.

Chen, C. F. 2006. Applying the analytical hierarchy process (AHP) approach to convention site selection. Journal of Travel Research 45(2), 167-174.

Crouch, G. I., Brent Ritchie, J. R. 1997. Convention site selection research: A review, conceptual model, and propositional framework. Journal of Convention E Exhibition Management 1(1), 49-69.

Crouch, G. I., Weber, K. (2002). Marketing of convention tourism. In: Weber, K., Chon, K.S. (Eds.) Convention tourism: International research and industry perspectives. Haworth Hospitality Press, New York, 57-78.

Crouch, G. I., Louviere, J. J. 2004. The determinants of convention site selection: A logistic choice model from experimental data. Journal of travel research 43(2), 118-130.

DiPietro, R. B., Breiter, D., Rompf, P., Godlewska, M. 2008. An exploratory study of differences among meeting and exhibition planners in their destination selection criteria. Journal of Convention \& Event Tourism 9(4), 258-276.

Dragićević, V., Blešić, I., Stankov, U. 2010. Satisfaction and Behavioral Intentions of Congress Attendees: Evidence from an International Congress in Novi Sad (Serbia). Geographica Pannonica 14(1), 23 - 30.

Dragićević, V., Jovičić, D., Blešić, I., Stankov, U., Bošković, D. 2012. Business tourism destination competitiveness: A case of Vojvodina Province (Serbia). Economic research-Ekonomska istraživanja 25(2), 311-332.

Dragićević, V., Stankov, U., Armenski, T., Štetić, S. 2011. Evaluation of congress performance and congress attendees' satisfaction - a case study of Novi Sad (Serbia), Tourism and Hospitality Management 17(1), 67-78.

Dunjić, J., Dragićević, V., Arsenović, D., Pantelić, M., Stankov, U. 2012. Conference attendees' satisfaction: Evidence from Belgrade (Serbia). Turizam 16(4), 170-179.

German Convention Bureau (2013). Meetings and Conventions 2030: A study of megatrends shaping our industry. Available at https://www.gcb.de/trends-inspiration/meetings-and-conventions-2030.html.

Han, H., Hwang, J. 2017. What motivates delegates' conservation behaviors while attending a convention? Journal of Travel E Tourism Marketing 34(1), 82-98. https://doi.org/10.1080/1 $\underline{0548408.2015 .1130111}$ 
Han, H., Lee, S., Al-Ansi, A., Kim, H. C., Ryu, H. B., Kim, J. J., Kim, W. 2019. Convention Tourism and Sustainability: Exploring Influencing Factors on Delegate Green Behavior that Reduce Environmental Impacts. Sustainability 11(14), 3903. https://doi.org/10.3390/ $\underline{\text { su11143903 }}$

Houdement, J., Santos, J. A. C., Serra, F. 2017. Factors affecting the decision-making process when choosing an event destination: A comparative approach between Vilamoura (Portugal) and Marbella (Spain). Journal of Spatial and Organizational Dynamics 5(2), 127-145.

ICCA Statistics report 2019. Available on the website www.iccaworld.org.

Kim, W. G., Kim, H. C. 2004. The analysis of Seoul as an international convention destination. Journal of Convention E Exhibition Management 5(2), 69-87.

McCartney, G. 2008. The CAT (casino tourism) and the MICE (meetings, incentives, conventions, exhibitions): Key development considerations for the convention and exhibition industry in Macao. Journal of Convention E Event Tourism 9(4), 293-308.

Pavluković, V., Cimbaljević, M. 2020. Factors affecting conference participation decision-making. Journal of the Geographical Institute Jovan Cvijic 70(1), 31-43.

Qu, H., Li, L., Chu, G. K. T. 20oo. The comparative analysis of Hong Kong as an international conference destination in Southeast Asia. Tourism Management 21(6), 643-648.

Statistical Office of the Republic of Serbia (2020). Statistical Yearbook of the Republic of Serbia 2020. Statistical Office of the Republic of Serbia, Belgrade.

Swarbrooke, J., Horner, S. (2001). Business Travel and Tourism, Butterworth-Heinemann.

Tourism development strategy of the Republic of Serbia 2016-2025. Goverment of the Republic of Serbia, Ministry of Trade, Tourism and Telecommunications, Belgrade.

United Nations World Tourism Organization \& European Travel Commission (2015). The Decision-makingProcess of Meetings, Congresses, Conventions and Incentives Organizers. Madrid, Spain: UNWTO.

World Travel \& Tourism Council (2017). Maximising Opportunities for Business Travel Growth [Report]. Retrieved from https:/www.wttc.org/publications/2017/p4g-white-paper-maximising-opportunities-for-business-travel-growth/

Zhang, H. Q., Leung, V., Qu, H. 2007. A refined model of factors affecting convention participation decision-making. Tourism Management 28(4), 1123-1127. 